\title{
Requirements and modalities of ensuring success in academic learning
}

Florentina Mogonea, Florentin Remus Mogonea 


\title{
Requirements and modalities of ensuring success in academic learning
}

\author{
Florentina Mogonea ${ }^{a^{*}}$, Florentin Remus Mogonea ${ }^{b}$ \\ ${ }^{a, b}$ University of Craiova, 13, A.I. Cuza Street, Craiova, 200585, Romania \\ *Corresponding author: mogoneaf@yahoo.com
}

\section{Abstract}

Keywords:

success; academic learning; intellectual psychohygiene; mnemotechnics; stress management
Over time, the notion of learning has evolved, first of all under the influence of psychological theories, which address this fundamental human activity. Consonant with the current psychological and pedagogical conception on school learning, making it more effective is an important concern of every person preocuppied with personal development and success securement. This goal can be viewed from the perspective of both the learner and the teacher, who must facilitate this activity and provide the right scientific reference points, models, appropriate support, effective feedback and also support the learning process as a guarantee for the quality of the product.

The study aims to analyze the problematics of the factors and modalities that ensure or condition the efficiency of academic learning from the perspective of the future teacher students.

The investigation was carried out on a group of subjects, consisting of 69 master students from the Faculty of Letters, who are in their first year of master's degree studies and who, at the same time, attend the Psycho-pedagogical Training Program, level II.

The research method used was the survey based on the questionnaire, the applied tool being an opinion questionnaire with 16 different items: closed, semi-closed and open answers.

The research results have identified the factors, conditions and modalities that ensure the students' success in learning.

\section{Zusammenfasung}

Schlüsselworte: Erfolg; akademisches Lernen; intellektuelle Psychologie; Mnemotechnik; Stressmanagement.
Im Laufe der Zeit hat sich das Konzept des Lernens unter dem Einfluss psychologischer Theorien entwickelt, die sich hauptsächlich mit dieser grundlegenden menschlichen Aktivität befassen. Im Einklang mit der gegenwärtigen psychologischen und pädagogischen Konzeption des schulischen Lernens ist es ein wichtiges Anliegen jeder Person, die sich mit persönlicher Entwicklung und Erfolg beschäftigt, diese effektiver zu machen. Dies kann aus der Perspektive des Lernenden und dem Lehrers angesehen werden, das diese Tätigkeit erleichtern soll, Sehenswürdigkeiten wissenschaftliches Wissen, Modelle, eine angemessene Unterstützung, Feedback effektiv den Lernprozess zu unterstützen, als Sicherheit die Qualität des Produkts.

Die Studie zielt darauf ab, das Problem der Faktoren und Modalitäten zu analysieren, die die Effizienz des akademischen Lernens aus der Perspektive zukünftiger Lehramtsstudenten sicherstellen oder konditionieren.

Die Untersuchung wurde an einer Gruppe von Probanden durchgeführt, bestehend aus 69 Master-Studenten an der Fakultät für Literatur- und Sprachwissenschaften, im ersten Jahr der Master-Studiengänge -und zugleich die das psycho-pädagogisches Programm, II. Tiefebene besuchen.

Die verwendete Forschungsmethode war die Umfrage basierend auf dem Fragebogen, wobei das angewandte Tool ein Fragebogen mit 16 verschiedenen Fragebögen: geschlossen, halbgeschlossen, offen Antworten war.

Die Forschungsergebnisse haben die Faktoren, Bedingungen und Modalitäten identifiziert, die den Lernerfolg der Schüler gewährleisten.

\section{Introduction}

The learning activity, regardless of the age at which it occurs, is conditioned by a series of factors, from different categories, from the individual to the ones regarding environment, context, or the pedagogical ones. The complexity of the learning activity, the multitude of variables involved, sometimes make it difficult to manage. Knowing these factors, whether internal or external, can be an important step in trying to maximize their potential for a successful learning activity.
Academic learning allows perhaps more than other forms, the expression and interaction of numerous factors and various conditions that act together to ensure success. We are concerned with the analysis of this form of learning, especially for future teacher students, given their subsequent role in helping to educate students about their learning style, to teach them how to learn.

In the case of the students, we can speak of showing autonomy in learning, cognitive flexibility, an already formed learning style, whose effectiveness has been tested 
but which is permanently nuanced. The success of this activity is conditioned, in addition to the already mentioned elements, by the learner's level of expectancy, his expectations, how he relates to the learning task.

We consider it useful to take a look at the inventory of intellectual psychohygiene requirements, the modalities that contribute to the accomplishment of this activity from the perspective of the learners, in order to achieve a picture of the factors that ensure efficiency, quality and performance.

\section{Theoretical foundation}

The studies over the last decades have specified many factors that influence the academic performance of the students. According to (Shujaa, 1996, apud Mutsotso \& Abenga, 2010), they can be grouped into three categories:

- family background: socio-economic status, expectancies, involvement, parental support;

- student traits: adaptation skills, expectancies;

- school factor: high expectations, curriculum, teacher culture.

A large number of studies approach the individual learning conditions, given their variety and the rather large number. They can be cognitive, metacognitive, motivational, volitional, behavioral, attitudinal (Bannert \& Reimann, 2012, apud Backhaus, Jeske, Poinstingl, Koeni, 2017).

Motivation is one of the essential conditions of learning, as well as of any human activity. The students' motivation for learning has always been a challenge for any teacher and one of the causes that has led to difficulties in teaching. It is dependent on various age factors, the general psychological features specific to it, the specificity of each individual.

According to Keller (1984), motivation involves four key elements that interfere with the learning process: attention, relevance, confidence and satisfaction (ARCS model). Taking up Keller's model, later, Kahveci (2010, apud Yau, Cheng, Ho, 2015) adds 4 more elements to the already existing ones: Relevance, Interest, Confidence, Satisfaction, Personal Ability, Social Influence and Perseverance.

The Keller model was completed by Vincent (2003) and by Weibelzahi and Kelly (2005), as it can be observed in Figure no. 1.

Strongly related to motivation is also the value attributed to the working task, that is the interest in the task, its importance for the individual and its usefulness (Wigfield et al., 1997, apud Peklaj \& Levpušček, 2007).

In a diachronic and synchronic analysis of the reasons that determine students to learn, we are able to notice differences that can be characterized as belonging to that generation. Recent studies (Johnson \& Aragon, 2002, apud Razak, See, 2010) consider that the use of online learning environments can be a way to stimulate the students' motivation as it stimulates social interaction and manages to value the inter-individual differences.

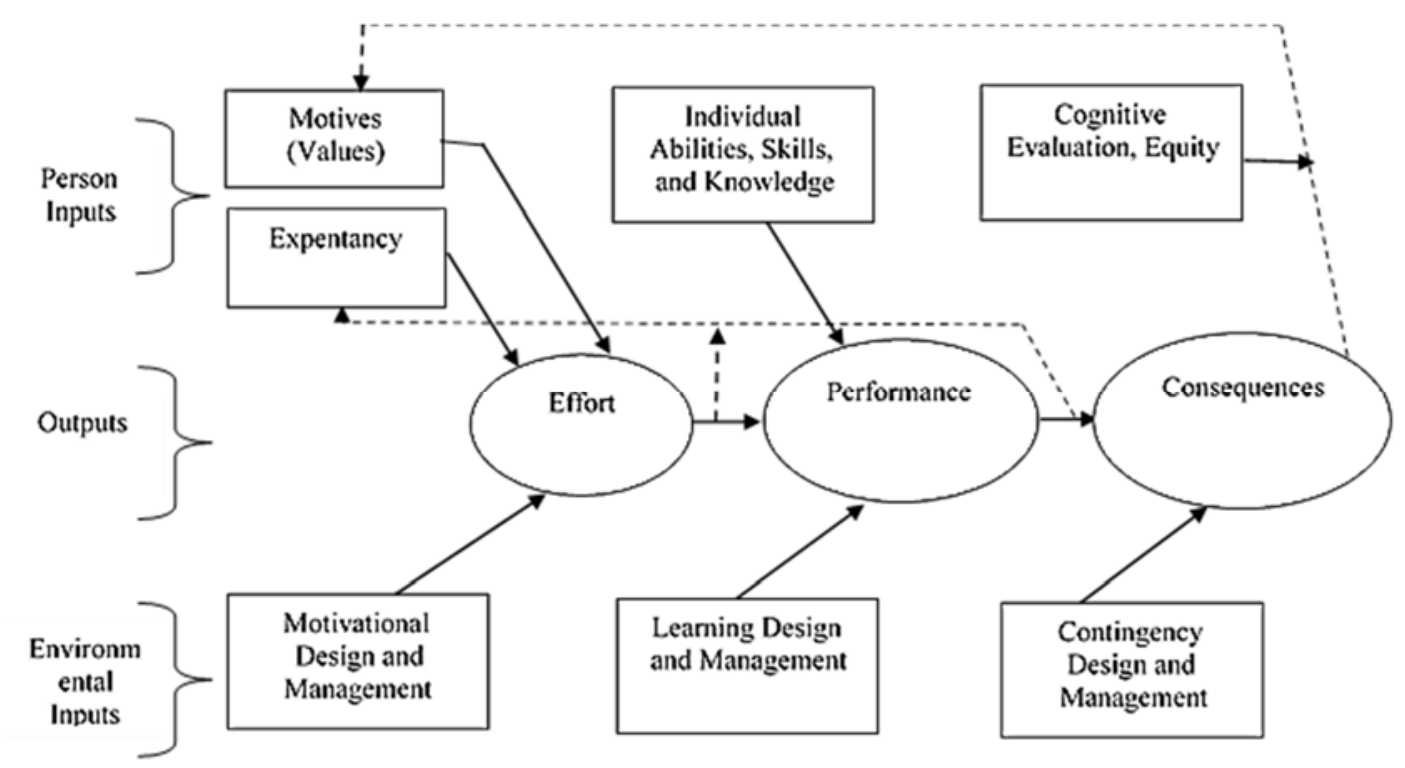

Figure no. 1. The Keller model, completed by Vincent (2003) and by Weibelzahi \& Kelly (2005), apud Bates, 2015, p. 
In academic learning there are also a number of factors and variables that condition efficiency, that need to be known in order to be controlled. Based on these variables, specialized literature records different intervention models, such as Hirsh's model (2001, apud Henning, 2009), a multiple intervention model that involves diagnosing problems and building an intervention plan.

Williams \& Williams (2011) mentions five important elements which are vital for improving the student's learning motivation: student; teacher; content; method/ process, and environment.

There are studies and research that investigate the effect of social motivation on the academic motivation of the students (Pânişoară, Duță, Pânişoară, 2015).
The educational environment is also one of the factors that condition effective learning. It has also evolved, over time, from the classical face-to-face type, to the virtual or blended learning one (Renner, Laumer, Weitzel, 2014).

The theory of social constructivism values the role of social learning, along with the individual one (Mogonea \& Mogonea, 2014a). The promotion of the students' engagement and the learning communities can also increase learning efficiency (Henard \& Leprince-Ringue, 2008).

The constructivist theory is also the one that promotes the role of experience in learning, which can be both a starting and a final point in a learning cycle (according to Kolb's model) (Fry, Ketteridge, Marshall, 2009, p. 15) (Figure no. 2).

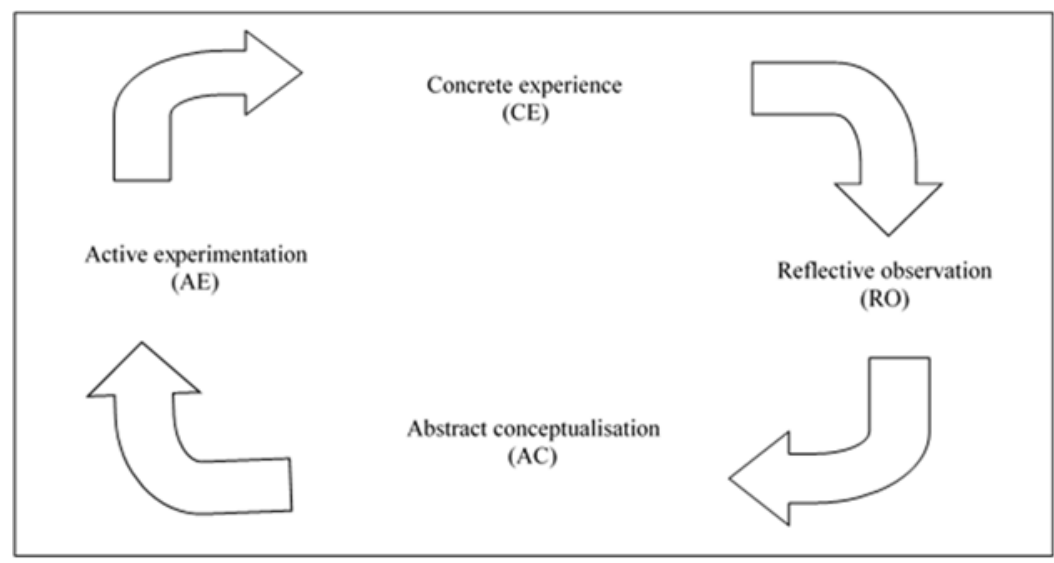

Figure no. 2. The Kolb Learning Cycle (apud Fry, Ketteridge, Marshall, 2009, p. 15)

The modality of stimulating motivation also requires instructional design principles. Hoskins \& Newstead (2009) propose a series of such principles (Table no. 1):

Table no. 1. Motivational generalisations and design principles (Pintrich, 2003, apud Hoskins \& Newstead, 2009,

Adaptive self-efficacy and competence beliefs motivate students.

Adaptive attributions and control beliefs motivate students.

Higher levels of interest and intrinsic motivation motivate students.
- Provide clear and accurate feedback regarding competence and selfefficacy, focusing on the development of competence, expertise and skill. - Design tasks that offer opportunities to be successful but also challenge students.

- Provide feedback that stresses process nature of learning, including importance of effort, strategies and potential self-control of learning.

- Provide opportunities to exercise some choice and control.

- Build supportive and caring personal relationships in the community of learners

- Provide stimulating and interesting tasks, activities, and materials, including some novelty and variety in tasks and activities.

- Provide content material and tasks that are personally meaningful and interesting to students. 
Higher levels of value motivate students.

Goals motivate and direct students.
- Display and model interest and involvement in the content and activities.

- Provide tasks, materials, and activities that are relevant and useful to students, allowing for some personal identification with learning.

- Classroom discourse should focus on importance and utility of content and activities.

- Use organisational and management structures that encourage personal and social responsibility and provide safe, comfortable and predictable environment.

- Use cooperative and collaborative groups to allow for opportunities to attain both social and academic goals.

- Classroom discourse should focus on mastery, learning, and understanding course and lecture content.

- Use task, reward and evaluation structures that promote mastery, learning, effort, progress and self-improvement standards and less reliance on social comparison or norm-referenced standards.
Schwartz, Son, Kornell and Finn (2011) propose four principles for improving memory as a condition for making learning more effective: 1) process material actively, 2) practice retrieval, 3) use distributed practice, and 4) use metamemory.

Group learning, carried out in a virtual environment, improves learning outcomes, collaboration, critical and reflective thinking, communication skills and understanding (Boud, 2001, apud Razak \& See, 2010). Some studies (Singh, Rylander, Mims, 2012) even make comparisons between students' outcomes in a virtual or a face-to-face learning environment.
The effectiveness of learning is also determined by the affective-emotional dimension of this activity. Controlling emotions and stress are requirements for success and performance in the academic activity, too (Durlak, Weissberg, Dymnicki, Taylor, Schellinger, 2011, Van Daele, 2013, Ketonen, 2017, Hj Ramli, Alavi, Mehrinezhad, Ahmadi, 2018).

There are studies exploiting one of the ideas of constructivism regarding the role of error and even failure in learning (van der Helden, Boksem, Blom, 2009).

There are numerous models of techniques, effective learning tools. In Table no. 2, we present some of these:

Table no. 2. Efficient Learning Techniques (Dunlosky et al, 2013, p. 6)

\begin{tabular}{|c|c|}
\hline Technique & Description \\
\hline $\begin{array}{l}\text { 1. Elaborative interrogation 3. Summarization Writing } \\
\text { summaries (of various lengths) of to-be-learned texts }\end{array}$ & $\begin{array}{l}\text { Generating an explanation for why an explicitly stated } \\
\text { fact or concept is true }\end{array}$ \\
\hline 2. Self-explanation & $\begin{array}{l}\text { Explaining how new information is related to known } \\
\text { information, or explaining steps taken during problem } \\
\text { solving }\end{array}$ \\
\hline 4. Highlighting/ underlining & $\begin{array}{l}\text { Marking potentially important portions of to-be- } \\
\text { learned materials while reading }\end{array}$ \\
\hline 5. Keyword mnemonic & $\begin{array}{l}\text { Using keywords and mental imagery to associate } \\
\text { verbal materials }\end{array}$ \\
\hline 6. Imagery for text & $\begin{array}{l}\text { Attempting to form mental images of text materials } \\
\text { while reading or listening }\end{array}$ \\
\hline 7. Rereading & Restudying text material again after an initial reading \\
\hline
\end{tabular}


8. Practice testing

9. Distributed practice

10. Interleaved practice
Self-testing or taking practice tests over to-be-learned material

Implementing a schedule of practice that spreads out study activities over time

Implementing a schedule of practice that mixes different kinds of problems, or a schedule of study that mixes different kinds of material, within a single study session
Another condition for success in learning, especially in the academic one, is the capitalization of metacognition, of personal reflection (Mogonea \& Ştefan, 2014, Zhao, Wardeska, McGuire, Cook, 2014, Mogonea, 2014), of cognitive flexibility, of autonomy in learning (Kormos \& Csizér, 2014, Ştefan, 2014), of cognitive and socio-cognitive conflicts (Mogonea \& Popescu, 2015). In addition to the metacognitive dimension, equally important is the non-cognitive dimension of personality, which often makes the difference between a successful or unsuccessful learning activity (Ștefan \& Mogonea, 2015).

Mnemotechnics, the use of graphical organizers, and cognitive maps can give consistency to certain learning strategies designed to ensure success (Mogonea \& Mogonea, 2014b). All these aspects are about ensuring a good self-management of the learning activity. (Frăsineanu, 2012).
1. Comprehensive student screening for emotional, behavioral, and learning difficulties. 2. Full assessment of at-risk individuals and their environments. 3. Schoolwide early intervention efforts that focus on prevention of more serious behavioral problems. 4. Comprehensive intervention carefully matched to the needs of the individual student. 5. evidence-based intervention strategies that are continually monitored for effectiveness. 6. Educational programs in which parents play an active and ongoing role.

Concluding, we can assume that, in order to achieve effective learning, we must follow the important variables of this activity, which arise as a response to some essential questions: Why? What? How? Where? When? Who with? We synthesized the answers to these questions in Figure no. 3 , which are as many conditions, efficiency factors.

Cohen (2006, p. 211), quoting Hunter (2005), mentions six principles of teacher-students collaboration that can provide a beneficial psycho-educational climate:

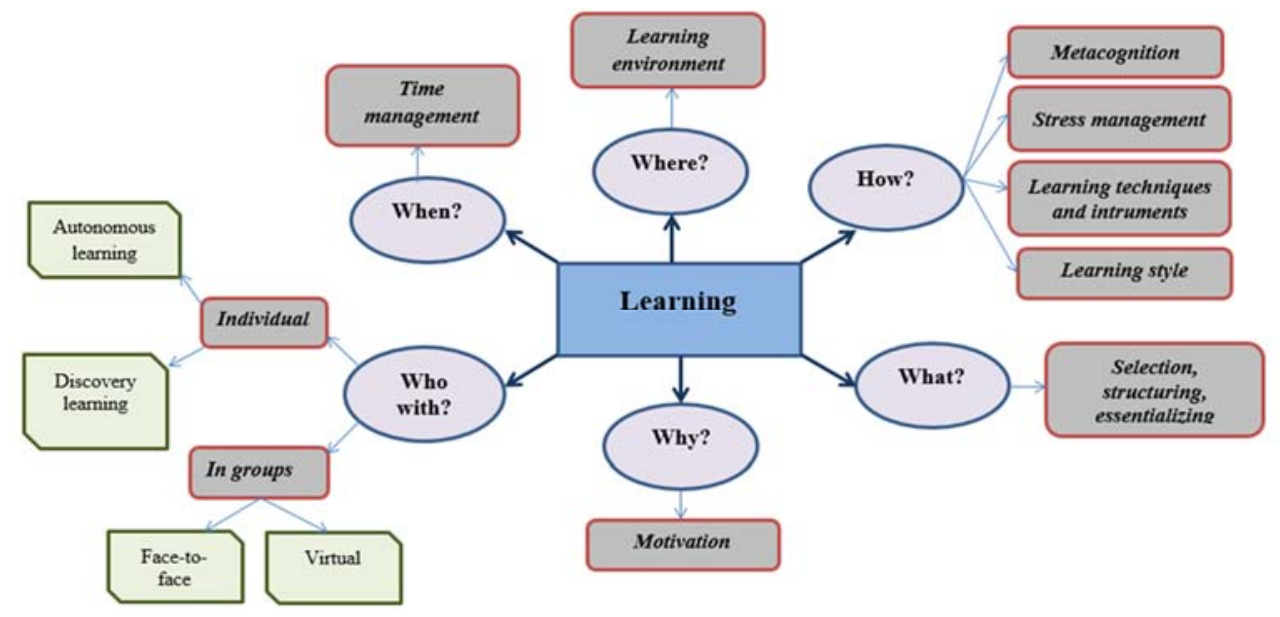

Figure no. 3. Variables of the learning activity 


\section{Research methodology}

The purpose of the research was to identify the factors and the conditions of efficiency in academic learning. Derived from this purpose, the research objectives were:

1. The knowledge of the reasons that determine the students' involvement in learning

2. The identification of the students' learning style characteristics

3. The establishing of the time management modalities

4. The knowledge of the conditions that ensure success in examinations

According to the above-mentioned goals, we verified the following hypotheses:

1. The knowledge and conformation to the factors and the internal and external learning conditions determine the success of the students in the exam.

2. The student's learning style is significantly determined by the specificity of the university specialization.

The research was carried out on a sample of 69 first year master students, from the Faculty of Letters, attending in parallel the Psycho-pedagogical Training Program, level II. The students included in the research sample have different specializations: Romanian, English, French, translators, music, acting.

The research method used was the survey based on the questionnaire, the tool being a questionnaire of 16 items, which allowed us to know the opinion of the subjects on the factors and conditions that provide an efficient learning, on their learning style, the learning techniques used, the modalities of managing time, stress, of monitoring and activity regulation. Most of the items were closed-ended, simple-choice but also multi-choice, and an open-response item as well.

\section{Results and discussions}

In order to verify the hypotheses of the research, we present the results obtained after applying the opinion questionnaire.

The first hypothesis of the research was as follows:

1. The knowledge and conformation to the factors and the internal and external learning conditions determine the success of the students in the exam.

To verify this hypothesis, we present the answers of the students to items $1,3,5,6,7,8,9,10,11,15$.

The first item of the questionnaire investigated the opinion of the subjects on the rhythm of preparation for exams.

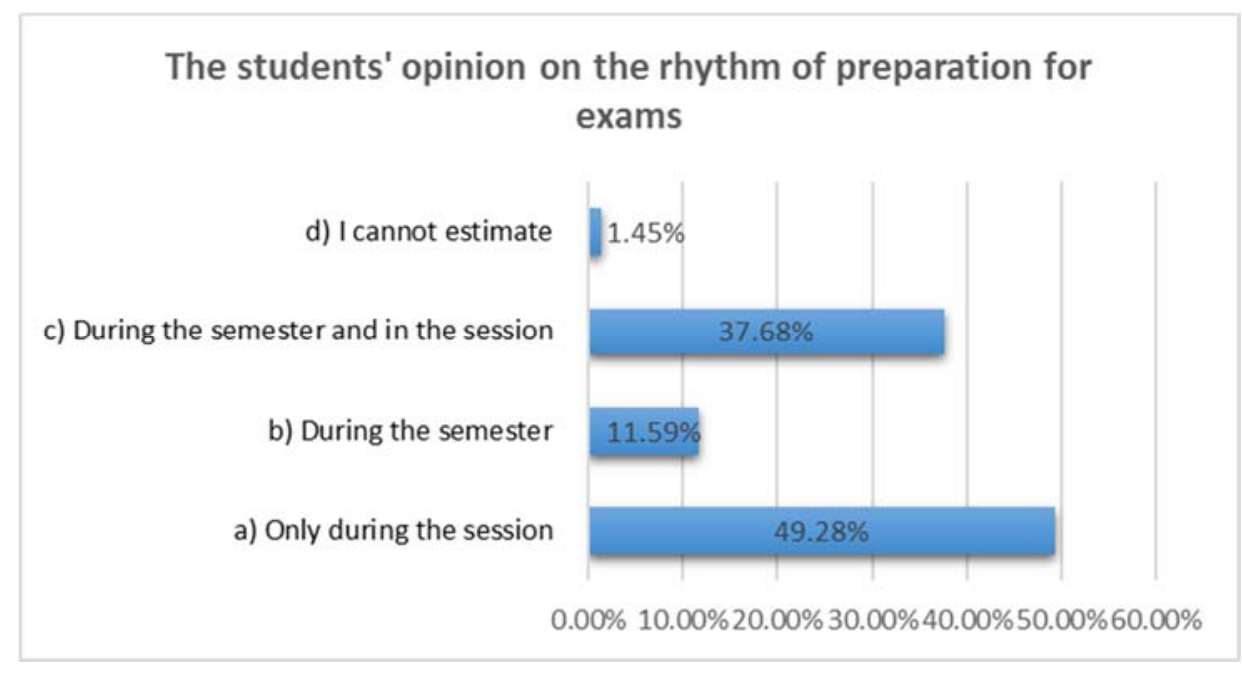

Figure no. 4. The students' opinion on the rhythm of preparation for exams 
As there can be seen in chart 4 , almost half of the students admit that they prepare for exams only during the session, and only $37.68 \%$ admit that they also do this during the semester. External environmental conditions are also important for the success of learning.

Figure no. 5 presents the hierarchy made by the students for some of the external learning conditions.

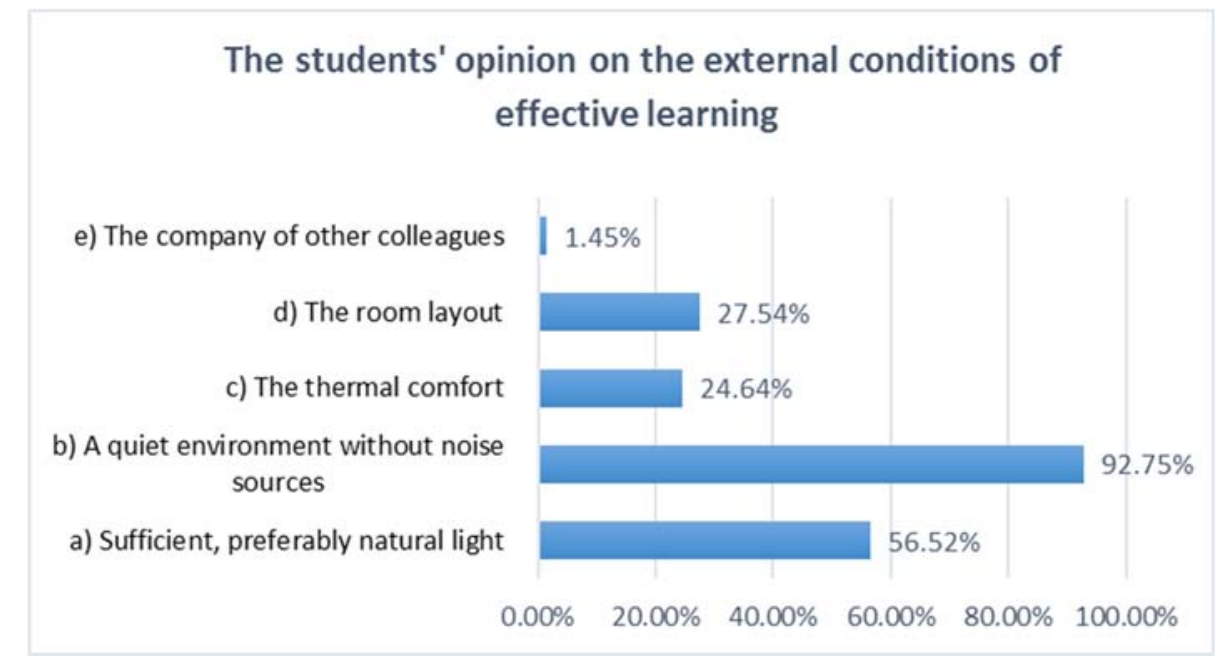

Figure no. 5. The students' opinion on the external conditions of effective learning

Almost all students (92.75\%) felt that a quiet environment without noise sources is the most important condition of learning. Also, good light and the aspect of the room are conditions to be followed.
Also related to the learning environment, most students think $(81.17 \%)$ that this should be done in any space where you feel comfortable, only $14.49 \%$ considering the place must be fixed, for example in the study, at the desk (Figure no. 6).

According to the students' answers, they sometimes make a day or hour planning of learning.

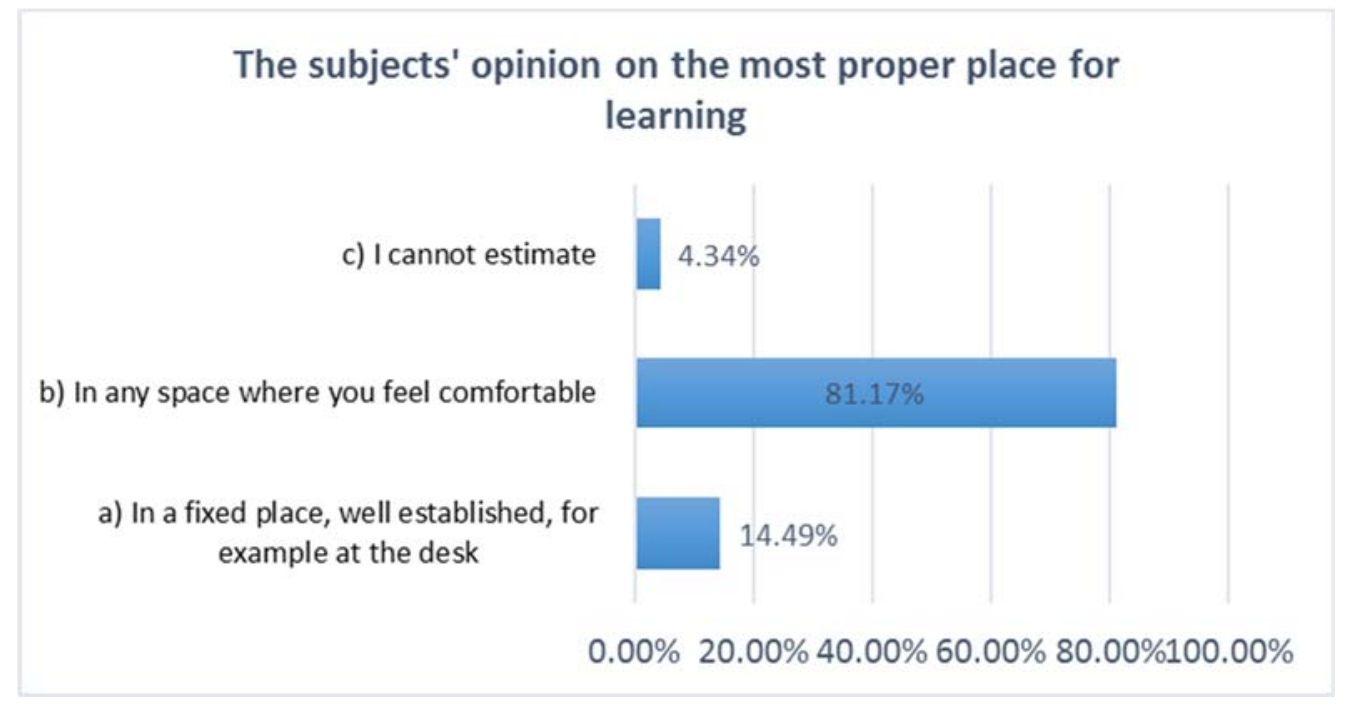

Figure no. 6. The subjects' opinion on the most proper place for learning 
Item 6 was an open-ended one, asking students to mention 3 conditions that ensure effective learning and success in exams.

The most frequently mentioned efficiency conditions were:

- Emotional stability;

- Structuring the subject;

- Making a sufficient number of repetitions;

- Using memory techniques, such as: using patterns, highlighting essential information, reading loudly;
- Understanding the notes;

- Rhythm in learning;

- Sufficient rest;

- Attending courses;

- Physical and mental comfort;

- Quiet environment;

- Qualities, features such as: spontaneity, intelligence, creativity, logical thinking, motivation, ability to concentrate.

- According to the students' answers, they sometimes make a day or hour planning of learning.

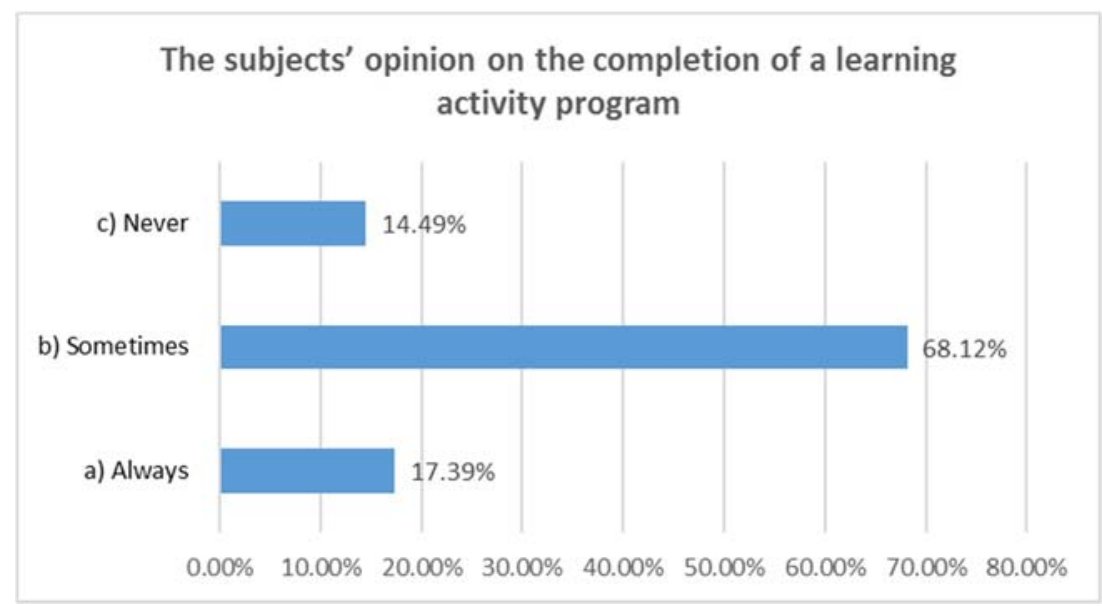

Figure no. 7. The subjects' opinion on the completion of a learning activity program

The same answers were also given to item 8 , on the frequency of self-evaluation at the end of a learning activity.

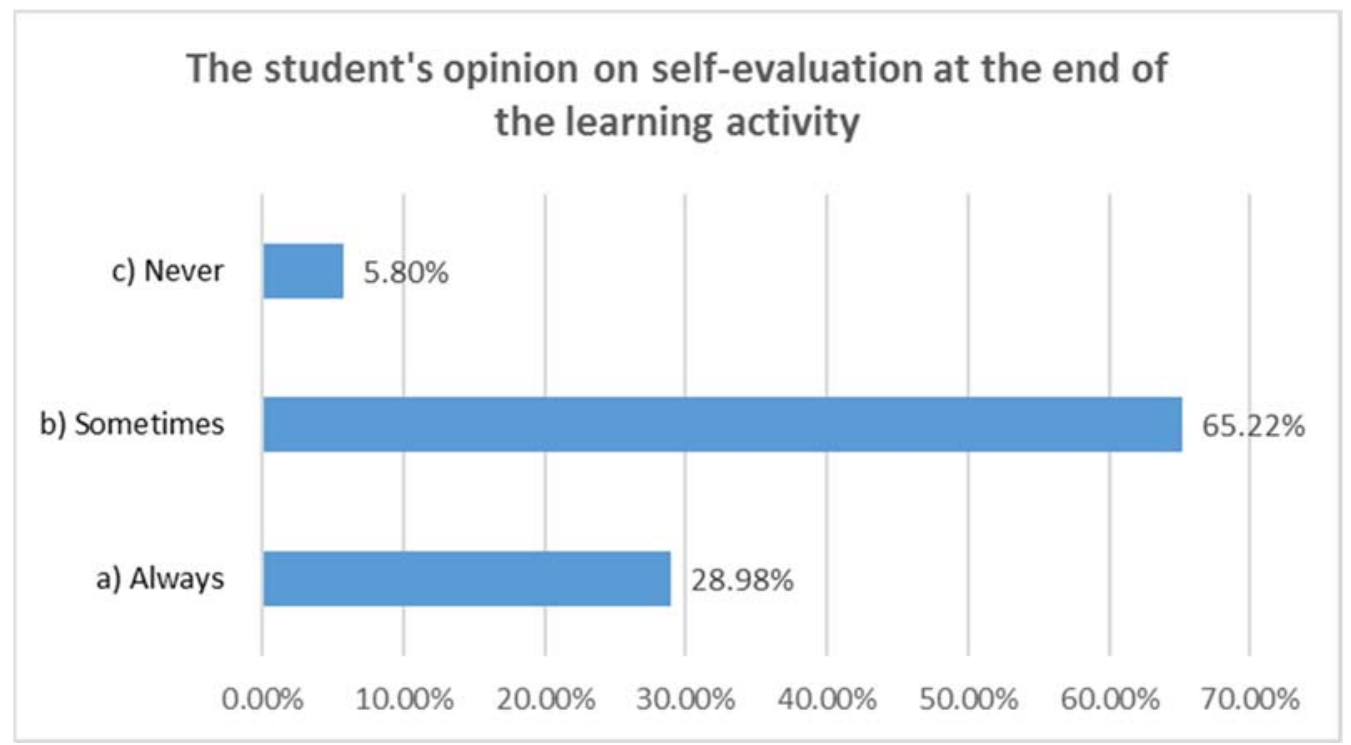

Figure no. 8. The student's opinion on self-evaluation at the end of the learning activity 
More than half of the surveyed students consider that they can only sometimes succeed to fit in time when they learn (Figure no. 9).

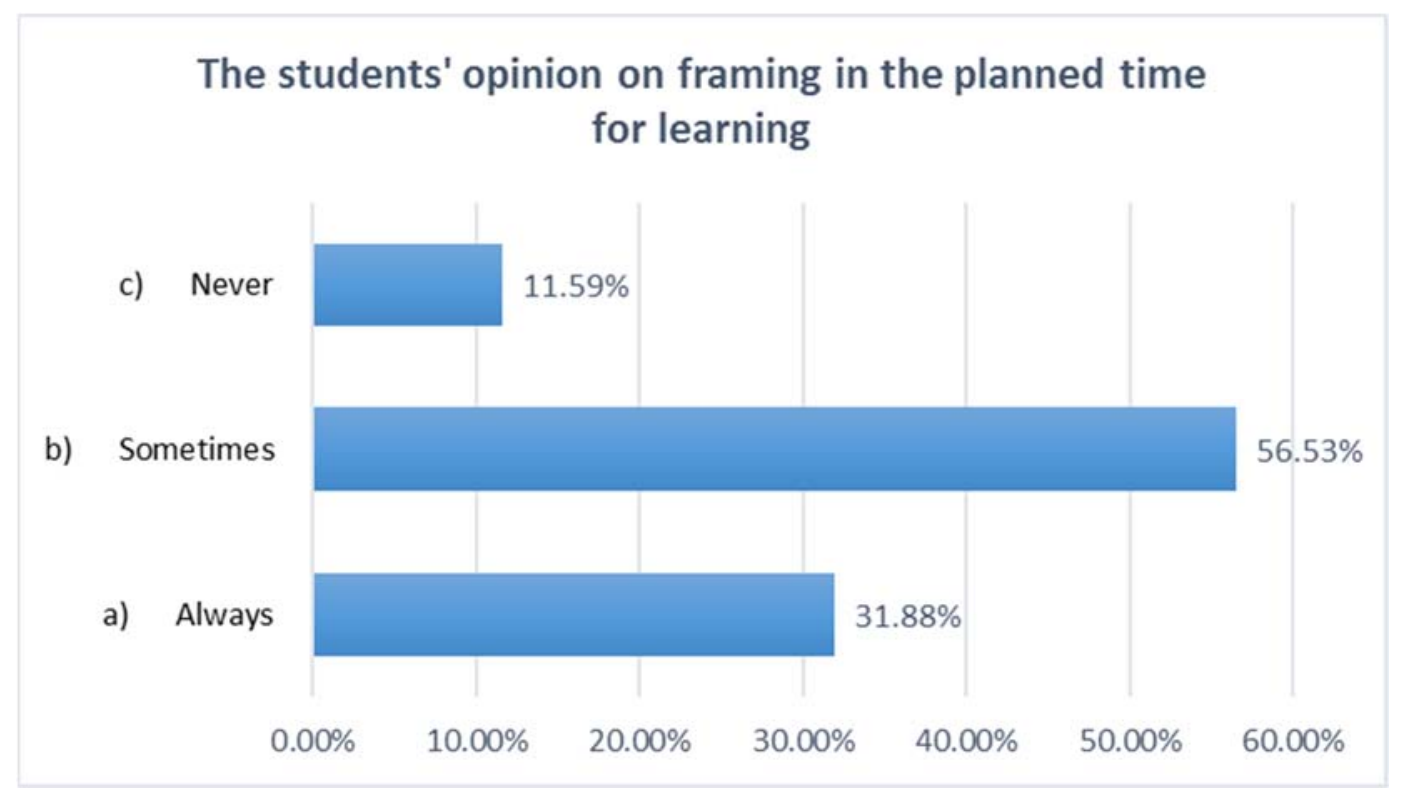

Figure no. 9. The students' opinion on framing in the planned time for learning

According to the answers given to the previous items, the students appreciate that they only sometimes manage to self-analyze their learning activity in order to establish its effectiveness. The distribution of responses on the three response variants is as follows: a) Always - 28.98\%; b) Sometimes $-65.22 \%$; c) Never $-5.80 \%$.
The students mostly admit that there are events, situations that may affect their learning activity, their ability to concentrate. The answers to this item are shown in Figure no. 10.

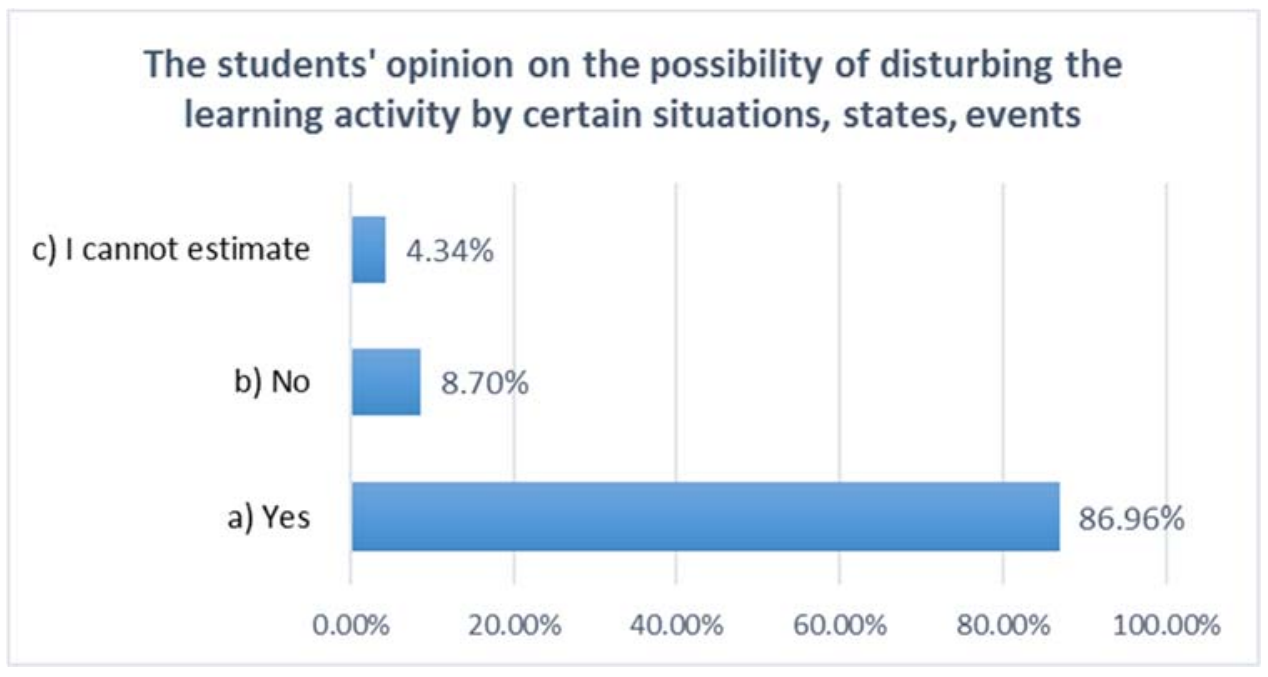

Figure no. 10. The students' opinion on the possibility of disturbing the learning activity by certain situations, states, events

One of the items of the questionnaire aimed at knowing the motivation of learning. 
Their answers are shown in Figure no. 11.

The student's opinion on the reasons for engaging in the learning activity

e) Another variant. Which one?

d) The perspective of professional or personal development

c) A possible failure to pass the exam

b) The perspective of the reward, namely of a good score on the exam

a) Preference for that particular subject

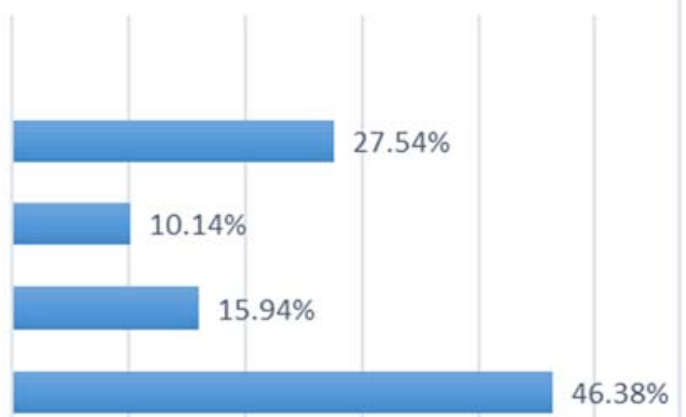

$\begin{array}{llllll}0.00 \% & 10.00 \% & 20.00 \% & 30.00 \% & 40.00 \% & 50.00 \%\end{array}$

Figure no. 11. The student's opinion on the reasons for engaging in the learning activity

As you can see, the preference for a certain subject is the most powerful reason for learning.

Hypothesis no. 2 of the research was as follows:

2. The student's learning style is significantly determined by the specificity of the university specialization
In order to verify this hypothesis, we present the students' answers to items 2, 4, 12, 13, 14, 16.

Item 2 wanted to identify the students' learning techniques. Their answers are shown in Figure no. 12.

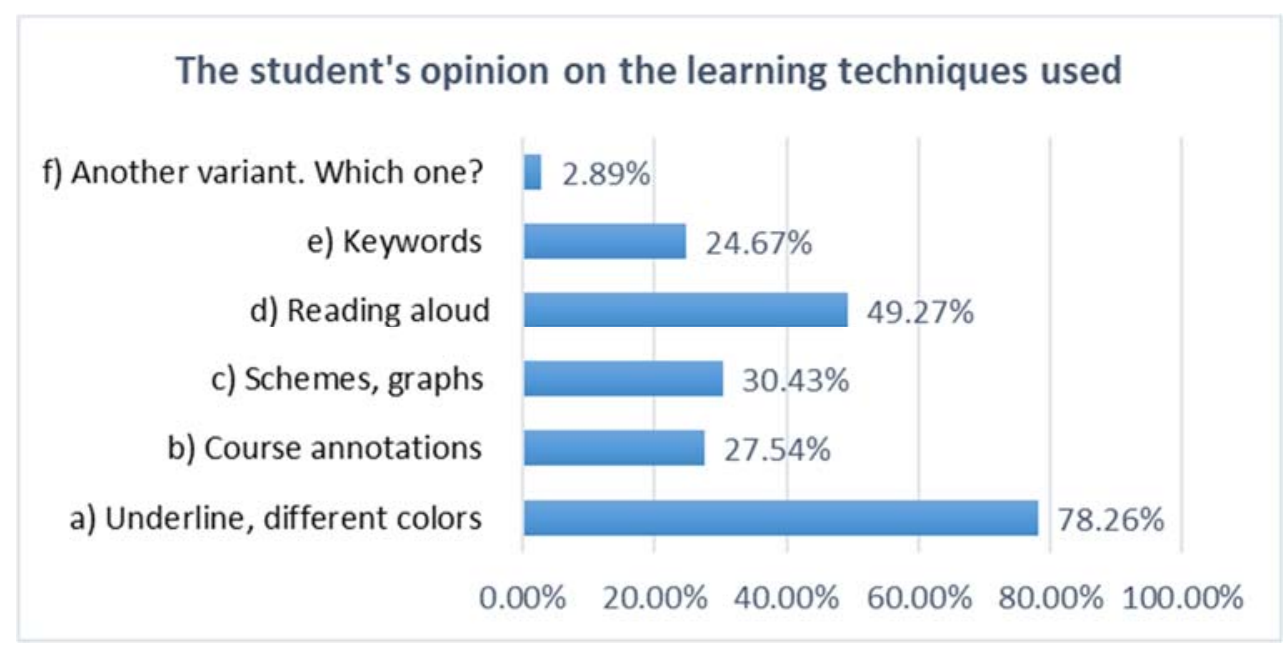

Figure no. 12. The student's opinion on the learning techniques used

For most of the students questioned the underlining is the way considered the most effective. Another option appreciated by the students is the one about the annotations on the courses. Surprisingly, there is the reading aloud version that has gathered the appreciation of almost half of the subjects. The explanation for this choice is related to the specifics of the specializations to which the students in the sample of subjects belong to, all of whom are students at the Faculty of Letters.

$78 \%$ of the students believe that their learning style is effective, as shown by their answers to item 4 . 
Also related to the students' learning style, one of the items of the questionnaire aimed at gathering information about how students learn, alone or in the company of other colleagues.

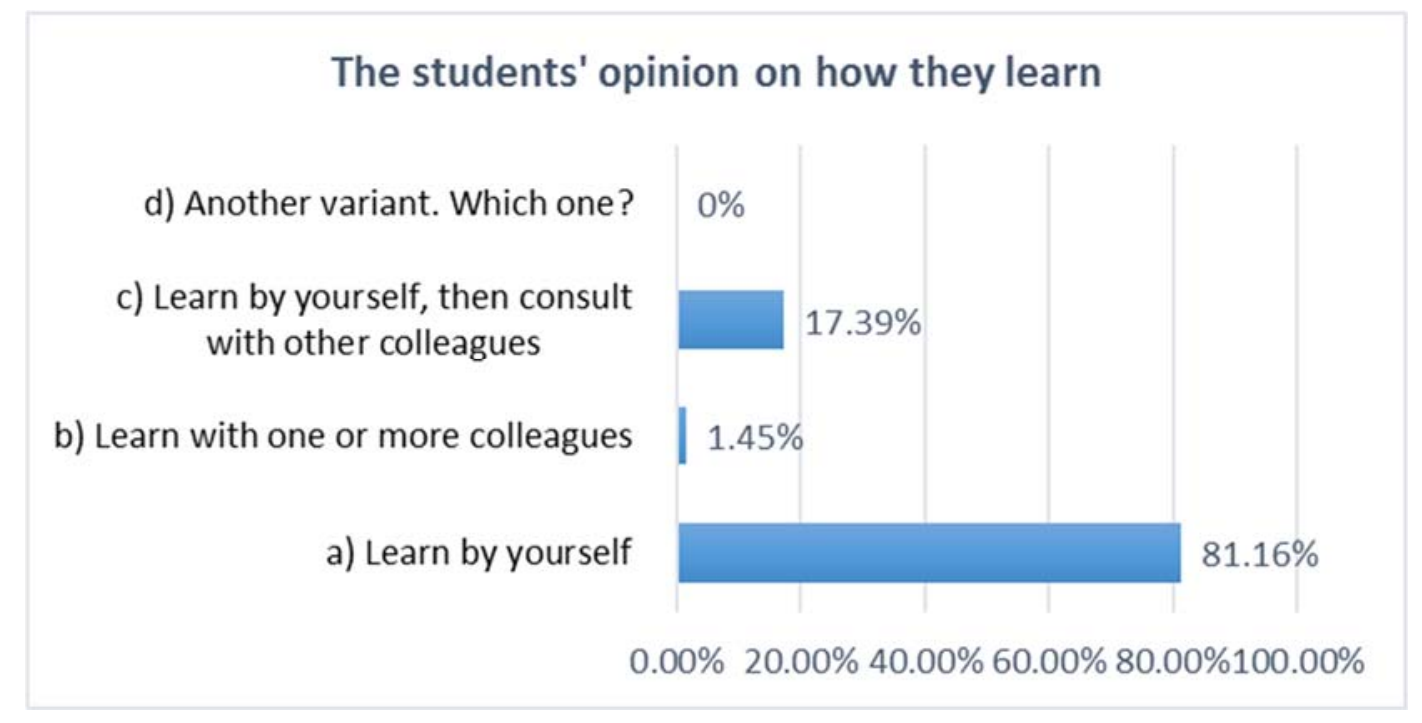

Figure no. 13. The students' opinion on how they learn

Most of the students said that they learnt alone.

If they have learning difficulties, they are turning to ... (see Figure no. 14).

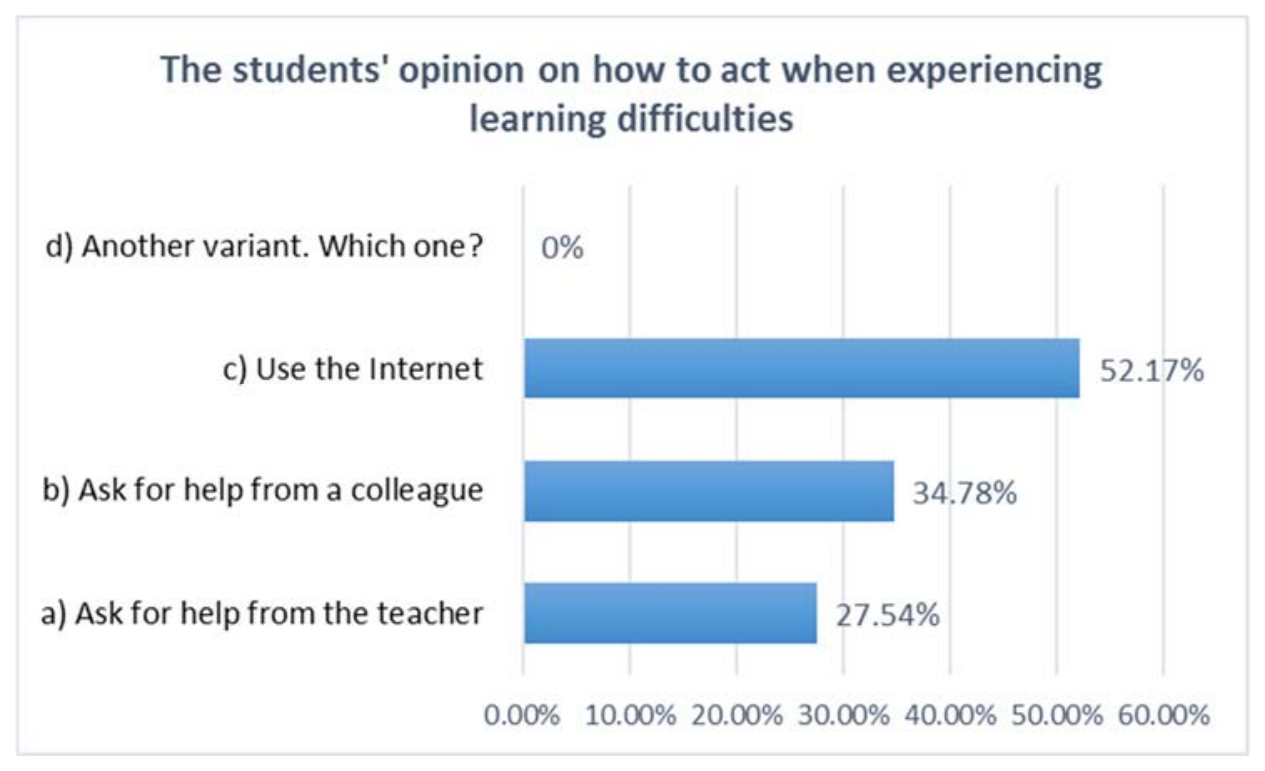

Figure No. 14. The students' opinion on how to act when experiencing learning difficulties

As there can be seen in Figure no. 14, the most frequent option in the students' choices was the appeal to the possibilities offered by the Internet, but this can also be explained by the specificity of the students' specialization, preponderantly theoretical.
Item 16 of the questionnaire asked students to estimate the conditions for successful examinations. Being a multiple-choice item, students were able to choose several variants.

Their answers are presented in Figure no. 15. 


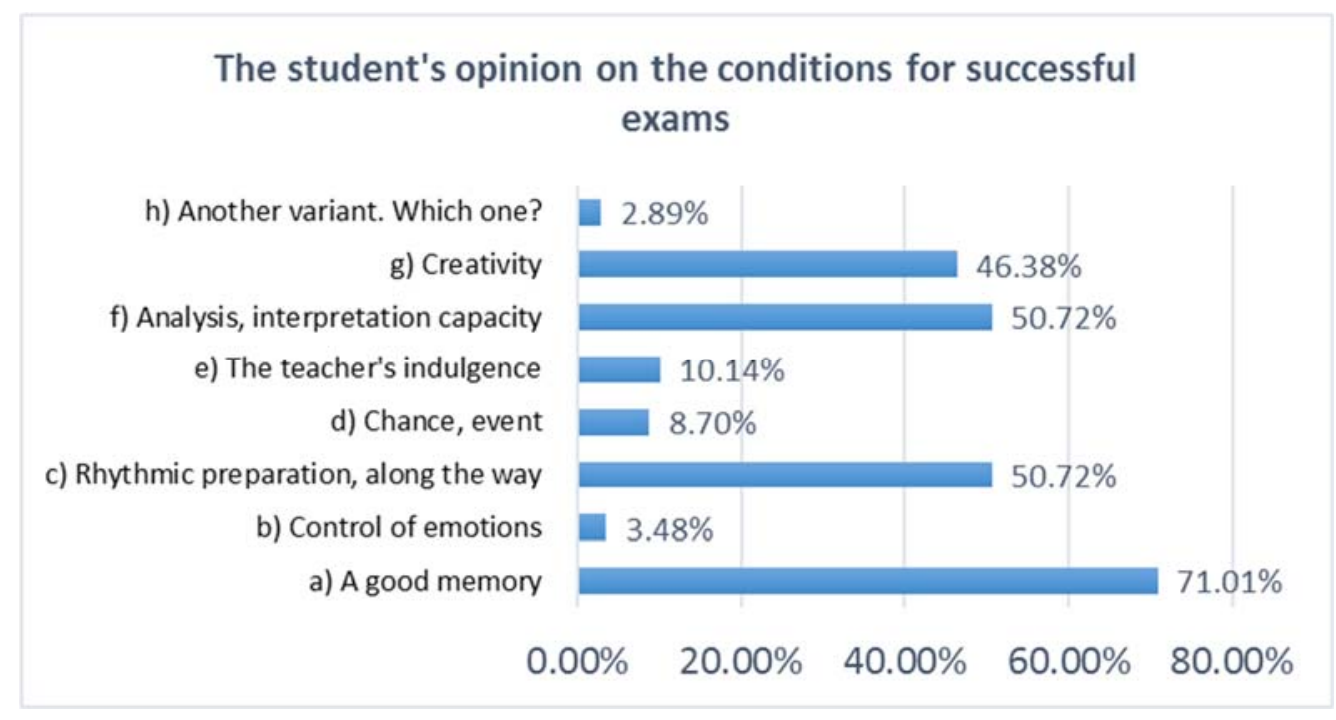

Figure no. 15. The student's opinion on the conditions for successful exams

As you can see, many of the surveyed students (71.01\%) consider the memory capacity as the most important condition for success. Good values have also been recorded in the variants referring to the rhythm of preparation, the ability to analyze and interpret and also creativity.

\section{Conclusion}

The learning activity is characterized by a special complexity, being sustained, determined by a series of factors, conditions, from the ones of an external nature to the internal ones. The way all these variables combine and how they influence the quality of this activity determines the level of success.

Our study has highlighted the specificity of academic learning, which are the conditions that, in the students' opinion, ensure efficiency. We have thus been able to identify the elements that ensure success in the exams, which underlie an effective learning, to what extent external or internal conditions may influence the quality of the service. Our conclusions support the idea that the students' choice for a particular learning style, whose effectiveness has been tested, is clearly influenced by the specificity of the specialization. We have also found that, if the internal and external learning conditions are known and respected, it can have great chances of success.

Efficient learning is clearly conditioned by good management of time and emotions, stress, good selfmonitoring and self-regulation of it, and also an adequate motivation.

The investigation made it possible to formulate relevant conclusions, but also outlined certain limits, related to the sample of subjects, which can be extended, by also including some students from other faculties, specializations, and thus being able to perform comparative analyzes.

\section{Authors note:}

Florentina Mogonea is Ph.D. Associate Professor, Teacher Training Department, University of Craiova, Director of the Psycho-pedagogical Research Center, Editor in-chief of the Academic Publication Annals of the University of Craiova, Psychology-Pedagogy series. Competence fields: Pre- and in-service training of teachers; theory and practice of school assessment; management and leadership of the class of students; educational research; sociology of education.

Florentin Remus Mogonea is Ph.D. Associate Professor, Doctor of Education Sciences, Teacher Training Department, University of Craiova, permanent member of the Psycho-pedagogical Research Center, Editor of the Academic Publication Annals of the University of Craiova, Psychology-Pedagogy series. Competence fields: Pre- and in-service training of teachers; theory and practice of school assessment; management and leadership of the class of students; educational research; sociology of education. 


\section{References}

Backhaus, J., Jeske, D., Poinstingl, H., Koeni, S. (2017). Assessing Efficiency of Prompts Based on Learner Characteristic. Computers, 6 (7), 1-15. Available at: doi:10.3390/computers6010007, [online, 01.06.2018].

Bates, C.M.F. (2015). Learner Characteristics and Motivation: How to Achieve Efficient and Effective Learning. Collected Essays on Learning and Teaching, VIII, 165-170. Available at: https://files.eric.ed.gov/fulltext/EJ1069721.pdf, [online, 01.06.2018].

Boud, D. (2001). Introduction: Making the move to peer learning. In D. Boud, R. Cohen, \& J. Sampson. Peer Learning for Higher Education, pp. 1-20. London: Kogan Page Limited.

Cohen, J. (2006) Social, Emotional, Ethical, and Academic Education: Creating a Climate for Learning, Participation in Democracy, and Well-Being. Harvard Educational Review, 76 (2), 201-237. Available at:

http://ww.ijvs.org/files/Publications/Social,\%20Emotional,\% 20Ethical.pdf, [online, 01.06.2018].

Durlak, J.A.,Weissberg, R.P., Dymnicki, A.B., Taylor, R.D., Schellinger, K.B. (2011). The Impact of Enhancing Students' Social and Emotional Learning: A Meta-Analysis of School-Based Universal Interventions. Child Development, 82 (1), 405-432. Available at: https://novofoundation.org/wpcontent/uploads/2012/07/Meta-Analysis-ChildDevelopment-Full-Article.pdf [online, 01.06.2018].

Frăsineanu, E.S. (2012). Invățarea și self-managementul invățării eficiente în mediul universitar. Craiova: Universitaria Publishing House.

Fry, H., Ketteridge, S., Marshall, S. (2009). Understanding student learning, in H. Fry, Ketteridge, S., S. Marshall (eds.). A Handbook for Teaching and Learning in Higher Education Enhancing Academic Practice, third edition. New York: Routledge, 8-26.

Henard, F., Leprince-Ringue, S. (2008). The path to quality teaching in higher education. Available at: http://www.oecd.org/education/imhe/44150246.pdf, [online, 01.06.2018]

Henning, M.A. (2009). Students' Motivation to Access Academic Advising Services NACADA Journal, 29 (1), 2230. Available at:

http://nacadajournal.org/doi/pdf/10.12930/0271-951729.1.22? code=naaa-site. [online, 01.06.2018].

Hj Ramli, N.H., Alavi, M., Mehrinezhad, S.A., Ahmadi, A. (2018). Academic Stress and Self-Regulation among University Students in Malaysia: Mediator Role of Mindfulness, Behavioral Sciences, 8 (12), 1-9. Available at: doi:10.3390/bs8010012, [online, 01.06.2018].

Hoskins, S.L., Newstead, S.E. (2009). Encouraging student motivation, in H. Fry, Ketteridge, S., S. Marshall (eds.). A Handbook for Teaching and Learning in Higher Education Enhancing Academic Practice, third edition. New York: Routledge, 27-39.

Keller, J.M. (1984). The use of the ARCS model of motivation in teacher training. In K. S. A. J. Trott (Ed.). Aspects of educational technology, volume XVII: Staff development and career updating. London: Kogan Page.
Ketonen, E. (2017). The Role of Motivation and Academic Emotions in University Studies The short- and long-term effects on situational experiences and academic achievement. Helsinki Studies in Education, 18. 5-10. Available at:

https://helda.helsinki.fi/bitstream/handle/10138/228581/The Roleo.pdf?sequence=1 [online, 01.06.2018].

Kormos, J., Csizér, K. (2014). The Interaction of Motivation, Self-Regulatory Strategies, and Autonomous Learning Behavior in Different Learner Groups. Tesol Quarterly, 48 (2), 275-299. Available at:

https://onlinelibrary.wiley.com/doi/epdf/10.1002/tesq.129, [online, 01.06.2018].

Mogonea, F. (2014). Premise teoretice şi metodologice ale valorificării metacogniţiei în activitatea didactică. Craiova: Sitech Publishing House.

Mogonea, F. R., Mogonea, F. (2014a). Constructivist teaching and valorization of the independent activity based on collaboration and cooperation. Procedia Social and Behavioral sciences, 127, 184-188. Available at: http://ac.els-cdn.com/S1877042814023283/1-s2.0S1877042814023283-main.pdf?_tid=e66e0b58-d794-11e3b5dc00000aab0f6b\&acdnat $=1399652207$ d59b496b6a0cd2181b caec5b371f0fa0, ISSN: 1877-042, [online, 01.06.2018].

Mogonea, F.R., Mogonea, F. (2014b). The Constructivist Teaching and the Optimization of Learning through Cognitive Maps. Procedia Social and Behavioral sciences, 128, 164-168. Available at: http://www.sciencedirect.com/science/article/pii/S18770428 14022289, [online, 01.06.2018].

Mogonea, F., Popescu, A.M. (2015). The role of sociocognitive conflict in academic-type learning. Procedia Social and Behavioral sciences, 180, 865-870. Available at: http://ac.els-cdn.com/S1877042815015748/1-s2.0S1877042815015748-main.pdf? tid=4996180a-0a03-11e5bdea00000aacb362\&acdnat $=1433344674 \_5 \mathrm{fd} 3 \mathrm{ff} 033 \mathrm{f} 73 \mathrm{~b} 7 \mathrm{e} 8 \mathrm{e} 88 \mathrm{e}$ 6ac71d8eec9f, [online, 01.06.2018].

Mogonea, F., Ştefan, M.A. (2014). Personal reflection and learning efficientization. Journal Plus Education, 10 (1), 298-311. Available at:

http://uav.ro/jour/index.php/jpe/article/view/239/253, [online, 01.06.2018].

Mutsotso, S.N., Abenga, E.S.B. (2010). Study methods for improving quality learning and performance in higher education. Educational Research and Review, 5 (12), 808813, Available at: http://www.academicjournals.org/ERR, [online, 03.06.2018].

Pânişoară, G., Duţă, N., Pânişoară, I.-O. (2015). The influence of reasons approving on student motivation for learning. Procedia - Social and Behavioral Sciences 197, 1215-1222. Available at: doi: 10.1016/j.sbspro.2015.07.382, [online, 03.06.2018].

Peklaj, C., Levpušček, M.P. (2007). Students' motivation and academic success in relation to the quality of individual and collaborative work during a course in Educational Psychology. Association of Teacher Education in Europe, 31st Annual ATTEE Conference. University of Ljubljana, 
Slovenia. Available at: http://www.pef.uni-lj.si/atee/978961-6637-06-0/147-161.pdf, [online, 02.06.2018].

Razak, R.A., See, Y.C. (2010). Improving academic achievement and motivation through online peer learning. Procedia Social and Behavioral Sciences, 9, 358-362. Available at: doi:10.1016/j.sbspro.2010.12.164, [online, 03.06.2018].

Renner, D., Laumer, S., Weitzel, T. (2014). Effectiveness and Efficiency of Blended Learning - A Literature Review.

Twentieth Americas Conference on Information Systems, Savannah, 1-13. Available at:

https://aisel.aisnet.org/cgi/viewcontent.cgi?article=1286\&co ntext=amcis2014, [online, 01.06.2018].

Singh, S., Rylander, D.H., Mims, T.C. (2012). Efficiency of Online vs. Offline Learning: A Comparison of Inputs and Outcomes. International Journal of Business, Humanities and Technology, 2 (1), 93-98. Available at: http://ijbhtnet.com/journals/Vol_2_No_1_January_2012/12. pdf [online, 01.06.2018].

Schwartz, B.L., Son, L.K., Ko.rnell, N., Finn, B. (2011). Four Principles of Memory Improvement: A Guide to Improving Learning Efficiency. The International Journal of Creativity \& Problem Solving, 21(1), 7-15. Available at: https://sites.williams.edu/nk2/files/2011/08/Schwartz.Son_. Kornell.Finn_.2011.pdf, [online, 05.06.2018].

Ștefan, M.A. (2014). Dezvoltarea competenței de învățare autonomă la studenți. Craiova: Sitech Publishing House.

Ştefan, M.A., Mogonea, F. (2015). Non-cognitive determinants of the academic learning. Asian Academic Research Journal of Social Sciences and Humanities, 1 (34) (April-2015), Online ISSN: 2278 - 859X, 123-140. Available at: http://www.asianacademicresearch.org/current.html, [online, 01.06.2018].

Van Daele, T. (2013). A Psychoeducational Approach to Stress Management. An Implementation and Effectiveness Study, doctoral dissertation. Faculteit Psychologie en Pedagogische Wetenschappen. Available at: https://www.kuleuven.be/lucas/nl/Publicaties/publi_upload/ Doctoral_dissertation_TomVanDaele.pdf, [online, 03.06.2018].

van der Helden, J., Boksem, M.A.S., Blom, J.H.G. (2009). The Importance of Failure: Feedback-Related Negativity Predicts Motor Learning Efficiency. Cerebral Cortex, 20, 1596-1603. Available at: doi:10.1093/cercor/bhp224, [online, 01.06.2018].

Williams, K., Williams, C. (2011). The influence of reasons approving on student motivation for learning. Research in Higher Education Journal, 11, 1-23. Available at: https://scholarsarchive.library.albany.edu/cgi/viewcontent.cg i? referer=https://www.google.ro/\&httpsredir $=1 \&$ article $=100$ $0 \&$ context $=$ math_fac_scholar, [online, 01.06.2018].

Yau, H.K., Cheng, A.L.F., Ho, W.M. (2015). Identify the Motivational Factors to Affect the Higher Education Students to Learn Using Technology. TOJET: The Turkish Online Journal of Educational Technology, 14 (2). Available at: http://www.tojet.net/articles/v14i2/14212.pdf, [online, 07.06.2018].

Zhao, N., Wardeska, J.G., McGuire, S.Y., Cook, E. (2014). Metacognition: An Effective Tool to Promote Success in College Science Learning. Journal of College Science Teaching, 43 (4), 48-54. Available at: http://deltastate.edu/PDFFiles/Academic\%20Affairs/teachin g-and-learning-resources/metacognition-an-effectivetool.pdf, [online, 07.06.2018]. 